\title{
GOOD CORPORATE GOVERNANCE, CONSERVATISM ACCOUNTING, REAL EARNINGS MANAGEMENT, AND INFORMATION ASYMMETRY ON SHARE RETURN
}

\author{
Sugiyanto, Alexander Candra \\ Accounting Department Pamulang University \\ Email: giant card@yahoo.com
}

\author{
ARTICLE INFO: \\ Article History: \\ Received 22 May 2018 \\ Revised 15 June 2018 \\ Accepted 15 July 2018 \\ JEL Classification: \\ G34, M41, M49 \\ Keywords: \\ Good Corporate \\ Governance, \\ Conservatism, \\ Real Earnings \\ Management, \\ Information Asymmetry, \\ and Stock Return
}

\begin{abstract}
This study aims to analyze the influence of accounting conservatism, real earnings management, and information asymmetry on stock returns. This study uses the sample of all manufacturing companies listed on the Indonesia Stock Exchange during the period 2013 to 2015. The total number of companies used as sample research is 44 companies with observations for three years. Pursuant to purposive sampling method, total of research sample is 132 financial reports and annual reports. The results of this study indicate: (1) Good corporate governance has a significant negative effect on stock return with a significance value of $0.002<0.050$; (2) Conservatism with accrual-based conservatism proxy has a significant negative effect on stock return with a significance value of $0.032<0.050$; (3) Real earnings management with the proxy of discretionary cash flow has no effect on stock return with a significance value of 0.050; and (4) Information asymmetry with proxy of bid-ask spread has no effect on stock return with significance value of $0.453>0.05$.
\end{abstract}

\section{INTRODUCTION}

Company performance is a picture of the results or achievements that are influenced by operational activities in an effort to utilize the resources owned company during a certain period of time. In this study, the company's performance measure used is stock returns. Basic consideration of the selection of stock return sizes that shareholders have the motivation to invest in the hope of obtaining a return in accordance with the embedded capital.

Often the occurrence of several cases of accounting scandals that occur in the country, caused by cases of violations by some accountants, and lack of understanding in the capital market. The phenomenon in this study is due to decreased public opinion, trust and public assessment of the company's performance, especially companies that are in the capital market because of the lack of satisfaction of public opinion to investors, issuers, securities, and also analysts.

Information on company performance can be influenced by factors such as Kazemi's conservatism, Dechow, P.M, Skinner real earnings management (2000). This is because management can choose and change accounting policies, accounting estimates, and error corrections to improve the relevance and reliability of the entity's financial statements. They also can compare the financial statements over time, and compare the entity's financial statements with other companies. 
Good corporate governance is a system of checks and balances, both internal and external that ensures the company performs accountability to all stakeholders, and is socially responsible in its business activities. Corporate governance, from a narrow point of view, is defined as the relationship between the company and its shareholders (Solomon, 2014).

Based on existing practices, often the user's attention to financial statements is only directed to earnings information, regardless of how and where the earnings are generated. Management as the manager of the company has the obligation to provide information about the condition of the company to shareholders, but in this case the information submitted sometimes is not in accordance with the actual company conditions.

\section{LITERATURE REVIEW}

\section{Company Value Theory}

Duran (1952) Cost of the Debt and Equity Funds for Bussiness, the value of the Firm theory associated with the theory of financial structure. The company value theory views the firm as a set of contracts between many parties, where the company's financial structure has a considerable influence on firm value.

This study uses the theory of corporate value with the consideration that (1) conservatism is a prudent concept to keep the profit and assets not expressed too high and the stated burden and debt is not too low so that the financial statements presented have high quality financial information and will further affect company value, (2) real earnings management, and information asymmetry also affect company value.

\section{Information Asymmetry Theory}

Akerlof (1970) introduced the theory of information asymmetry through "The market for lemons". Akerlof connects quality and uncertainty and develops information asymmetry ideas or ideas by providing examples of used car markets. The reason of this research is using information asymmetry theory because information asymmetry will affect (1) stock price that occurs in market influenced by information factor and (2) existence of government policy affecting business environment.

\section{Signaling Theory}

Ross (1977) associates the theory of signal with the problem of asymmetry information between management and investors, regarding the structure of the firm's capital are determined by the incentive signal of the firm's management. Management with information advantage has an incentive to signal personal information through its debtrate options.

The reason this research uses signal theory is that every corporate action made by the company gives meaning to outsiders. The meaning given by the information is known as a signal, this can be a positive signal or a negative signal, followed by a market reaction. If the signal is positive, the market reacts so as to increase the stock price which further affects the company's performance. Furthermore, the increase in stock value reflects the improvement of company performance, in this case stock returns, return on equity, and earnings per share will increase. Variables that affect the signal are the quality of information provided by the company (Manurung, 2012).

\section{Agency Theory}

The agency theory was introduced by Jansen, M.C and Meckling W.H (1976). The idea of this theory is the separation of ownership and control of the firm. The agency theory states that there is an agency relationship as a contract between management as an agent with the owner as the company principal. The working 
relationship between the parties giving the authority (principal) that is the shareholder with the party who receives the authority (agent) that is management, in the form of a cooperation contract called "Nexus of Contract".

This research uses agency theory with the consideration that (1) seen from funding source, external funding of company comes from debt and stock, and (2) seen from organizational theory there are three strongly related parties in company, that is agent as manager, investor as the lender and the owner as a capital or fund-raiser to the company. The issue that arises in relation to the agent is the problem between the agent and the investor and the agent with the owner. In this case the management who manage the company as an agent plays a role in determining the company's performance.

\section{Good Corporate Governance}

Good corporate governance is the pillars of corporate governance with the environment of stakeholders' capital and human capital. Corporate governance is considered as one of the foundations of corporate governance to its ability to prepare companies with proper guidance, selfregulation, and open access to investment capital through its activities. The Forum Corporate Governance in Indonesia (FCGI) defines corporate governance as a set of rules that establishes relationships between shareholders, managers, creditor, government, employees, and other internal and external interest holders in relation to their rights and obligations, or in words another system that directs and controls the company.

\section{Conservatism}

Traditionally, accounting conservatism is defined as "anticipate no profit, but anticipate all losses" Bliss (1924) in Watt (2003). Anticipating no profit means not recognizing profits before there is valid verification of claims to revenue generating profits. This means conservatism is in the extreme form of not recognizing profits, but acknowledging any losses even though they have not been realized. So profits will only be recognized upon realization until there is a legitimate claim to such profits.

\section{Real Eanings Management}

Cohen, D.A and Zarowin P. (2010) define real earnings management as a change of time or the structure of a real business transaction to change profits, where real transaction changes deviate from optimal activity plans and impose real costs for the firm.

According to Roychowdhury (2006) earnings management through real activity is a deviation from the normal operating activities of a company that is motivated by management's desire to provide a false understanding to stakeholders that certain financial reporting objectives have been achieved through the company's normal operating activity. According to Gunny (2010) real earnings management is an action performed by management to change the time or structure of transactions of operations, investments and / or financing in an attempt to influence the output of the accounting system.

Based on the above definitions, it can be concluded that real earnings management is a deliberate management action by changing the time or structuring transactions operations, investments, or financing with the aim to declare profit is not real.

\section{Information Asymmetry}

Information asymmetry is a condition where one party has better information than 
the other. In a corporate context, managers have better information about the company's condition than investors who are not involved in management. Information asymmetry will raise an adverse selection problem because investors do not know for sure which companies are good and which are bad.

\section{Stock returns}

Company performance is a whole and comprehensive picture of the results or achievements that are influenced by the operational activities in exploiting resources owned by the company during a certain period of time. In other words, the company's performance is the level of achievement of results in order to realize the company's goals. Measuring company performance is important in the relationship between the company and its stakeholders.

Return of shares is a return from shares and the results of the broker or company to investors who have invested in the company. In the world of the stock market, an investor who invests by buying a stock must be confident with all the risks and uncertainties that will be obtained in the future. Because, the game of stock market is a bit much to rely on luck, although there are ways that technical techniques can be used by investors to get the best results.

\section{DATA AND RESEARCH TECHNIQUE ANALYSIS Population and Sample Research}

The population in the study is 182 manufacturing companies. This study uses the sample of all manufacturing companies listed on the Indonesia Stock Exchange during the period 2013 to 2015. The total number of companies used as sample research is 44 companies with the period of observations about three years.

In this research the technique is using analysis model of Dechow and Skinner (2000) for the accrual and profit management model. The population used in this study is a listed manufacturing sector company which published its annual report on Indonesia Stock Exchange (IDX) from the period 2013 to 2015. Meanwhile, sampling in this research used non probability sampling method with purposive sampling technique.

Data obtained from www.idx.co.id in the form of annual reports and corporate financial statements. Stock return data, and bid-ask spreads for Indonesia are obtained from finance.yahoo.com. The composite share price index data for Indonesia is obtained from website www.idx.go.id.

Table 1. Operational Variables of Measurement

\begin{tabular}{|c|c|c|c|}
\hline Variable & Measurement & Scale & Referents \\
\hline $\begin{array}{c}\text { Good } \\
\text { Corporate } \\
\text { Governance } \\
\text { (X1) }\end{array}$ & $\begin{array}{l}\text { Good corporate governance is measured } \\
\text { using disclosure method or content analysis } \\
\text { based on five principles and concept } \\
\text { (concept) using dichotomy that is score } 1 \\
\text { (one) if yes do, and score } 0 \text { (zero) if not do } \\
\text { with total maximum percentage of weight of } \\
\text { score is } 100 \% \text {. The number of weighting } \\
\text { scores is calculated by the formula: value } 1 \text { : } \\
\text { express disclosure value } 0 \text { : states not } \\
\text { disclose ASEAN capital market forum } \\
\text { (ACMF), ASEAN corporate governance } \\
\text { scorecard } n \times 100 \% \text {. K Where: GCG: ASEAN } \\
\text { corporate governance scorecard indeks. }\end{array}$ & Ratio & $\begin{array}{c}\text { Ross A and } \\
\text { Crossn. K (2012) } \\
\text { ASEAN capital } \\
\text { market forum } \\
\text { (ACMF.2014) }\end{array}$ \\
\hline
\end{tabular}




\begin{tabular}{|c|c|c|c|}
\hline Variable & Measurement & Scale & Referents \\
\hline $\begin{array}{l}\text { Conservatism } \\
(\mathrm{X} 2)\end{array}$ & 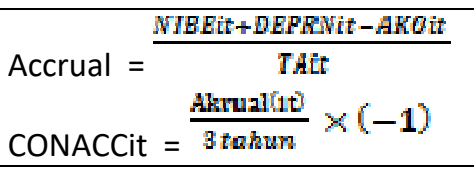 & Ratio & $\begin{array}{l}\text { Lee and T.J Wong } \\
\qquad(2010)\end{array}$ \\
\hline $\begin{array}{l}\text { Real Earnings } \\
\text { Management } \\
\text { (X3) }\end{array}$ & Cash flow discretionary $=\frac{C F O_{(i t)}}{T A(i t-1)}$ & Ratio & $\begin{array}{l}\text { Roychouwdhury } \\
\qquad(2006)\end{array}$ \\
\hline $\begin{array}{l}\text { Information } \\
\text { Asymmetry } \\
(\mathrm{X} 4)\end{array}$ & Spread $=\frac{a s k(i t)-b i d(i t)}{[a s h[i t)+b i d(i t)] / 2}$ & Ratio & $\begin{array}{l}\text { Callahan et al } \\
(1997)\end{array}$ \\
\hline $\begin{array}{l}\text { Stock Return } \\
(\mathrm{Y})\end{array}$ & Stock return $=\frac{F(t)-P[t-1]}{P t-1}$ & Ratio & Hartono (2013) \\
\hline
\end{tabular}

STOCK RETURN $=\alpha 0+\beta 1 G C G+\beta 2$ CONSERVATISM + $\beta 3$ REAL EARNING MANAGEMENT + BUINFORMATION ASYMMETRY + et.

In this research the data is collected by means of documentary collection, i.e. the use of data derived from existing documents. This is done by tracking and recording the necessary information on secondary data in the form of financial statements and annual reports of sample companies. Other supporting data were obtained by using literature study from scientific journals and literature containing the discussion related to this research. Data obtained from www.idx.co.id in the form of annual reports (annual report), and corporate financial statements Stock return.

\section{RESULT AND DISCUSSION}

\section{Descriptive Statistic}

Descriptive analysis is a method in which all data related to the study are collected and grouped for analysis and interpretation objectively by comparing the minimum, maximum and average values of the sample.

Table 2. Descriptive Statistics

\begin{tabular}{|c|c|c|c|c|c|}
\hline & $\mathbf{N}$ & Minimum & Maximum & Mean & $\begin{array}{c}\text { Std. } \\
\text { Deviation }\end{array}$ \\
\hline GCG & $32^{1}$ &,- 88300 & ,74530 &,- 0478826 & ,34736481 \\
\hline KON & $32^{1}$ &,- 98300 & ,64530 &,- 1478826 & ,24736481 \\
\hline REM & $3^{1}$ &,- 37930 & ,63820 & ,0800780 & ,12693781 \\
\hline IA & $32^{1}$ &,- 52630 & 2,00000 & ,0820258 & 31287747 \\
\hline RETURN & $32^{1}$ &,- 00890 & ,00750 &,- 0007402 & ,00252378 \\
\hline Valid N (listwise) & $32^{1}$ & & & & \\
\hline
\end{tabular}

Source : Self Proceed 


\section{Normality test}

Normality test is performed to determine whether the data is normally distributed or not. Because a good regression model has normal data distribution. There are 2 ways to detect the normality of data that is by graph analysis and statistical test. To test the normality of data in this study using histogram graph analysis and normal plot graph and using statistical test by using KolmogorovSmirnov (K-S) test.

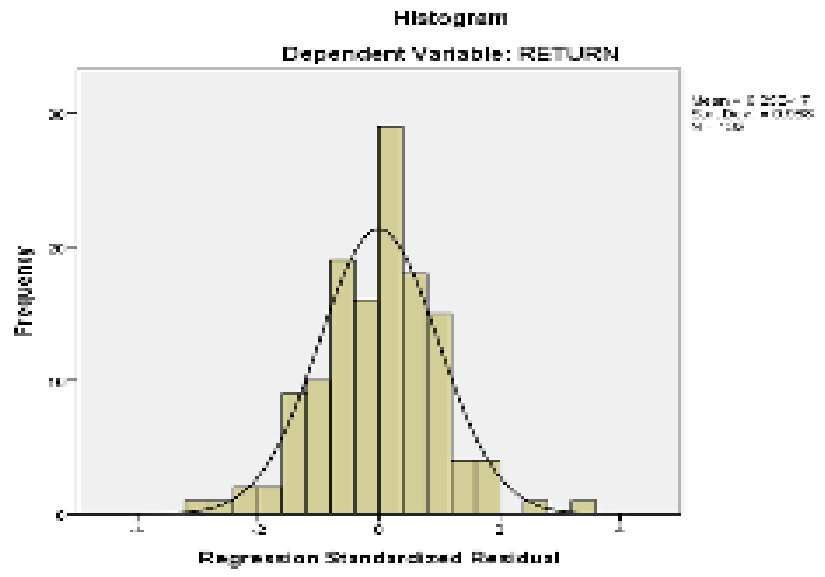

Figure 1. Test Normalitas Histogram Normal

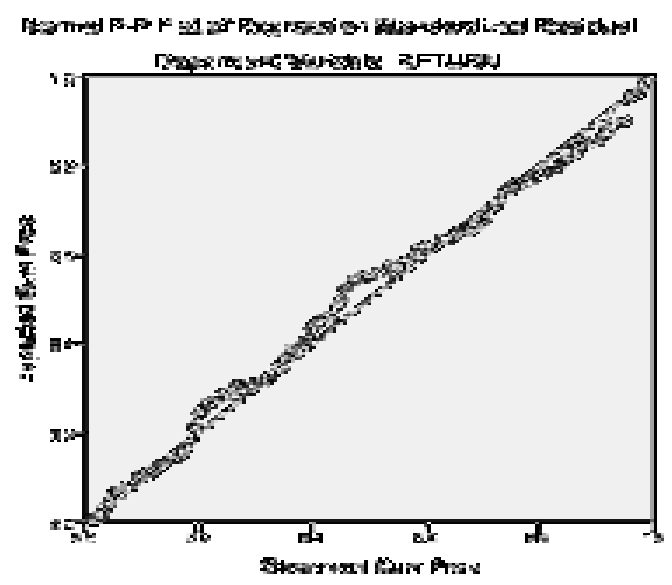

Figure 2. Test Normalitas Grafik Normal Plot

\section{Multicollinearity Test}

Multicollinearity test is performed to see if there is correlation between independent variables or each other. If the tolerance value $>0.1$ and $\mathrm{VIF}<10$, then it can be said there is no multicollinearity between independent variables. 
Table 3. Multicollinearity Test Coefficients ${ }^{a}$

a. Dependent Variable: RETURN

\begin{tabular}{|c|c|c|c|}
\hline \multicolumn{2}{|c|}{ Model } & \multicolumn{2}{|c|}{ Collinearity Statistics } \\
\hline & & Tolerance & VIF \\
\hline \multirow[t]{5}{*}{1} & (Constant) & & \\
\hline & GCG & ,999 & 1,001 \\
\hline & KON & ,999 & 1,001 \\
\hline & REM & ,999 & 1,001 \\
\hline & IA & 999 & 1,001 \\
\hline
\end{tabular}

Source : Self Proceed

\section{Autocorrelation Test}

Ghozali (2013), the autocorrelation test aims to test whether in a linear regression model there is a correlation between the confounding errors in period $t$ with the error of intruder in period $t$ with error period $t-1$ (previous). One measure in determining whether or not there is autocorrelation is to use the Durbin-Watson (DW) test. The Durbin Watson value between du and 4-du shows the model not affected by the autocorrelation problem.

Table 4. Auto correlation Test

\begin{tabular}{c|r|r|r|r|r}
\hline Model & $\mathrm{R}$ & $\begin{array}{c}\mathrm{R} \\
\text { Square }\end{array}$ & $\begin{array}{r}\text { Adjuste } \\
\mathrm{d} \text { R Square }\end{array}$ & $\begin{array}{r}\text { Std. Error of } \\
\text { the Estimate }\end{array}$ & $\begin{array}{c}\text { Durbin } \\
\text {-Watson }\end{array}$ \\
\hline 1 &, 256 &, 065 &, 043 &, 00246828 & 1,839 \\
\hline
\end{tabular}

a. Predictors: (Constant), IA, REM, KON, GCG

b. Dependent Variable: RETURN

Source : Self Proceed

\section{Heteroscedasticity Test}

The heteroscedasticity test was performed to test whether in the regression model there was a variance inequality of the residual one observation to the other. One way to detect whether or not heteroscedasticity is to see the scatterplot graph between the predicted value of the dependent variable is ZPRED with residual SRESID 


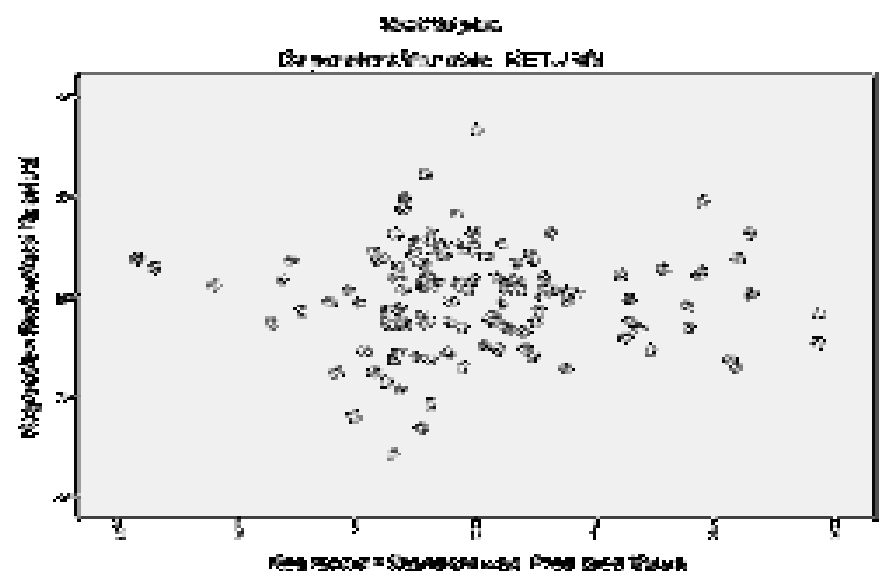

Source : Self Proceed

Figure 3. Heteroscedasticity Test Scatterplot Grafik

\section{Hypothesis Test Results}

Hypothesis testing in this study was conducted by using multiple regression analysis models. According to Ghozali (2015) multiple regressions is used to strengthen more than one independent variable to one variable. In this research, the experiment is done by testing the significance of individual parameters (t test statistic).
Individual Parameter Significance Test (Test Statistic t)

Partial test or $t$ test is used to show how far the influence of one independent variable individually in explaining the variation of the dependent variable tested at the 0.05 significance level. The $t$ test results are shown in Table 4.

Table 5. Statistical Test Results $t$ Coefficients ${ }^{\mathrm{a}}$

\begin{tabular}{|c|c|c|c|c|c|c|}
\hline \multirow{2}{*}{\multicolumn{2}{|c|}{ Model }} & \multicolumn{2}{|c|}{$\begin{array}{l}\text { Unstandardized } \\
\text { Coefficients }\end{array}$} & \multirow{3}{*}{$\begin{array}{l}\begin{array}{c}\text { Standardize } \\
\text { d Coefficients }\end{array} \\
\text { Beta } \\
, 000\end{array}$} & \multirow[t]{2}{*}{$\mathrm{t}$} & \multirow[t]{2}{*}{ Sig. } \\
\hline & & \multirow{2}{*}{$\begin{array}{r}\text { B } \\
- \\
, 001 \\
\end{array}$} & \multirow{2}{*}{\begin{tabular}{ll}
\multicolumn{2}{c}{ Std. } \\
Error \\
\end{tabular}} & & & \\
\hline 1 & (Constant) & & & & $-4,554$ & ,000 \\
\hline & GCG & - & ,001 &,- 285 & $-3,167$ & ,002 \\
\hline & KON & , 002 & ,001 &,- 185 & $-2,167$ & ,032 \\
\hline & REM & ,003 & ,002 & 169 & $\begin{array}{r}1,97 \\
7\end{array}$ & ,050 \\
\hline & IA & ,001 & ,001 & ,064 & ,753 & ,453 \\
\hline
\end{tabular}

a. Dependent Variable: RETURN

Source : Self Proceed

\section{CONCLUSION}

Based on the results of testing the discussion as has been presented in the previous section, it can be deduced with based on the test results with SPSS 24 that good corporate governance variable (X1) has a 
negative effect on stock return $\mathrm{H} 1$. Accounting conservatism variable $(\mathrm{X} 2)$ has a negative effect on stock return so $\mathrm{H} 2$ accepted. Variable real earnings management $(\mathrm{X} 3)$ does not affect the stock return so that $\mathrm{H} 3$ is rejected. Variable information asymmetry (X4) has no effect on stock return so $\mathrm{H} 4$ is rejected.

\section{Limitations}

The research has some limitations:

1. This research has limited resources and research information, in addition to the amount of data collected is not maximal due to limited use only financial statements of manufacturing companies that are listed on the Indonesia Stock Exchange. So the results of limited research generalization. The suggestion for further research is to expand the sample of companies by industry.

2. This study uses only manufacturing companies only. Subsequent research can use company samples for all industries, except for the financial industry because it has different characteristics.

3. This study calculates stock return without considering risk. Therefore it is necessary to calculate the stock return by using the risk adjusted return measure, so the estimation result is expected to be more precise.

\section{REFERENCES}

Akerlof, G. (1970). The Market for Lemons: Quality Uncertainty and the Market Mechanism. The Quarterly Journal of Economics.

Bliss, J.H. (1924). Management Through Accounts. New York: The Ronald Press Co.

Callahan, C.M., Lee, C.M., Yohn, T.L. (1997). Accounting Information and Bid Ask Spreads. Accounting Horizons, 11(4), pp 50-60.

Cohen, D.A. and Zarowi, P. (2010) Accrual
Based and Real Earnings Management Activities around Sesasonal Equity Offering, Journal of Accounting and Economics Vol. 50, pp 2-19.

Dechow, P.M., Kothari, S., Watts, R.L. (1998). The Relation between Earnings and Cash Flows. Journal of Accounting and Economics, 25(2), pp 133-168.

Dechow, P.M., Skinner, D.J. (2000). Management: Reconciling the Views of Accounting Academics, Practitioners, and Regulators. Accounting Horizons, 14, pp 232-250.

Duran, D. (1952). Cost of Debt and Equity Fund For Bussiness: Treand and Problems of Measurement Conference on Research in Business Finance. pp 212-265.

Ghozali, I. (2015). "Teori Akuntansi", Semarang: Badan Penerbit Universitas Diponogero.

Good Corporate Governance perspektif Manjemen Stratrgik www.iicg.org ASEAN Capital Market Forum (ACMF) 2014

Gunny, K.A. (2010). The Relation between Earnings Management Using Real Activities Manipulation and Future Performance: Evidence from Meeting Earnings Benchmarks. Contemporary Accounting Research, 27(3), pp 855-888.

Hartono, J. (2013). Teori Portofolio dan Analisis Investasi Edisi kedelapan BPFE Yogyakarta.

Ikatan Akuntan Indonesia. (2012), Standar Akuntansi Keuangan No. 25: Kebijakan Akuntansi, Perubahan Estimasi Akuntansi, Dan Kesalahan. Jakarta.

Jensen, MC. And Mackling, W.H. (1976) Theory of the Firm: Managerial Behavior Agency Costs and Ownership Structure. Journal of Financial Economics, Vol3 pp 305-360.

Kazemi, H., Hemmati, H., Faridvand, R. (2011). Investigating the Relationship between Conservatism Accounting and Earnings Attributes. World Applied Sciences 
Journal, 12(9), pp 1385-1396.

Lee and T.J Wong. (2010). Financial packaging of IPO corporate financial activites, analysts anad stock return, Chi dan $M$ Young, 2012 A review og earaning Management

Li, H. (2014). Top Executives' Ability and Earnings Quality: Evidence from the Chinese Ccapital Markets. International Journal of Financial Research, 5(4), pp 7986.

Manurung. (2012). Panduan Sukses Menjual Reksadana Jakarta: Grasindo.

Ross, S., Westereld, R., Jafe, J. (2013), Corporate Finance. 10th ed. New York: The McGraw-Hill Companies, Inc.

Ross A and Crossan K. (2012). A Review of the influence of Corporate Governance on the banking Crisis in the United Kingdom and Germany Corporate Governance Journal Vol 12 pp 215-225

Solomon, J. (2014). Corporate Governance and accontability (3rd ed) Hoboken: Wiley and Sons.

Roychowdhury, S. (2006). Earnings Management through Real Activities Manipulation. Journal of Accounting and Economics, 42, pp 335-370.

Watts, R.L. (2003), Conservatism in Accounting Part I: Explanations and Implications. Accounting Horizons, 17(3), pp 207-221. 